\title{
Comparative effectiveness of local treatment for low prostate- specific antigen, high Gleason score prostate cancer
}

\author{
Boda Guo $^{1,2} \wedge$, Ming Liu ${ }^{1,2} \wedge$ \\ ${ }^{1}$ Department of Urology, Beijing Hospital, National Center of Gerontology; Institute of Geriatric Medicine, Chinese Academy of Medical Sciences, \\ Beijing, China; ${ }^{2}$ Graduate School of Peking Union Medical College, Beijing, China \\ Correspondence to: Ming Liu. Department of Urology, Beijing Hospital, National Center of Gerontology; Institute of Geriatric Medicine, Chinese \\ Academy of Medical Sciences, Beijing, China; Graduate School of Peking Union Medical College, Beijing, China. Email: liumingbjhu@126.com. \\ Response to: Liu S, Wang XY, Huang TB, et al. Effect on survival of local treatment in patients with low prostate-specific antigen, high Gleason score \\ prostate cancer: a population-based propensity score-matched analysis. Ann Palliat Med 2020;9:1708-17.
}

Submitted Jul 28, 2020. Accepted for publication Sep 25, 2020.

doi: 10.21037/apm-20-1497

View this article at: http://dx.doi.org/10.21037/apm-20-1497

We read the study by Liu et al. (1) with great interest and would like to congratulate the authors for their superb study. The authors compared the oncologic outcomes of radical prostatectomy (RP) versus radiotherapy (RT) in low prostate-specific antigen (PSA) and high Gleason score (GS), prostate cancer $(\mathrm{PCa})$ patients. It deals with a significant clinical issue. As such, there are a few points that we would like to bring up.

As shown in Table 1, RP patients were younger and had an earlier $\mathrm{T}$ stage than their RT counterparts. Underlying selection biases in favor of RP patients may exist, such as better performance status and more stable hemoglobin concentration compared to the RT group. However, SEER database does not include the above data, so we could not completely account for selection biases related to physical condition. Fortunately, the database provides reasons why patients did not undergo surgery. One of the reasons is surgery was recommended by the doctor but the patient refused. In the study of Liu et al., the RT group can only include the above-mentioned patients who were appropriate surgical candidates; in this way, selection bias can be reduced to some extent.

Most patients who have undergone RP are cured of PCa. Patients with one or more adverse pathologic features (ie, positive margins, seminal vesicle invasion, extracapsular extension) may benefit from adjuvant RT (aRT)(2). However, Liu et al. did not include the information about aRT provided by the SEER database, which may have an unknown impact on their analysis. Another SEER-based study proved survival results with or without aRT were different among GS 9-10 PCa (3).

Liu et al.'s study included patients with primary $\mathrm{PCa}$ but did not exclude multiple primary cancers. However, a prior SEER-based study demonstrated there were at increased risk for cancers of soft tissue including heart, bladder, kidney, and endocrine system among PCa men compared with the general population (4).

\section{Acknowledgments}

Funding: None.

\section{Footnote}

Provenance and Peer Review: This article was a free submission to the journal. The article did not undergo external peer review.

Conflicts of Interest: Both authors have completed the ICMJE uniform disclosure form (available at http://dx.doi. org/10.21037/apm-20-1497). The authors have no conflicts of interest to declare.

Ethical Statement: The authors are accountable for all aspects of the work in ensuring that questions related

\footnotetext{
^ Boda Guo, ORCID: 0000-0001-8373-4584; Ming Liu, ORCID: 0000-0001-9557-5488.
} 
to the accuracy or integrity of any part of the work are appropriately investigated and resolved.

Open Access Statement: This is an Open Access article distributed in accordance with the Creative Commons Attribution-NonCommercial-NoDerivs 4.0 International License (CC BY-NC-ND 4.0), which permits the noncommercial replication and distribution of the article with the strict proviso that no changes or edits are made and the original work is properly cited (including links to both the formal publication through the relevant DOI and the license). See: https://creativecommons.org/licenses/by-nc-nd/4.0/.

\section{References}

1. Liu S, Wang XY, Huang TB, et al. Effect on survival

Cite this article as: Guo B, Liu M. Comparative effectiveness of local treatment for low prostate-specific antigen, high Gleason score prostate cancer. Ann Palliat Med 2020;9(6):44184419. doi: 10.21037/apm-20-1497 of local treatment in patients with low prostate-specific antigen, high Gleason score prostate cancer: a populationbased propensity score-matched analysis. Ann Palliat Med 2020;9:1708-17.

2. Thompson IM, Valicenti RK, Albertsen P, et al. Adjuvant and salvage radiotherapy after prostatectomy: AUA/ ASTRO Guideline. J Urol 2013;190:441-9.

3. Knipper S, Palumbo C, Pecoraro A, et al. Survival outcomes of radical prostatectomy vs. external beam radiation therapy in prostate cancer patients with Gleason Score 9-10 at biopsy: A population-based analysis. Urol Oncol 2020;38:79.e9-79.e14.

4. Davis EJ, Beebe-Dimmer JL, Yee CL, et al. Risk of second primary tumors in men diagnosed with prostate cancer: a population-based cohort study. Cancer 2014;120:2735-41. 